\title{
INFLUENCE OF THERMOMECHANICAL TREATMENT ON THE PROPERTIES OF COMMERCIAL ALUMINIUM ALLOYS FROM THE 6000 SERIES
}

\author{
VPLIV TERMOMEHANSKE OBDELAVE NA LASTNOSTI \\ KOMERCIALNIH ALUMINIJEVIH ZLITIN VRSTE 6000
}

\author{
Uroš Stamenković", Svetlana Ivanov, Ivana Marković, Dragoslav Gusković \\ Technical Faculty in Bor, University of Belgrade, Vojske Jugoslavije 12, 19210 Bor, Serbia \\ Prejem rokopisa - received: 2019-07-10; sprejem za objavo - accepted for publication: 2019-12-23
}

doi:10.17222/mit.2019.242

\begin{abstract}
The aim of this paper was to investigate the influence of thermomechanical treatment (TMT) on different properties of two commercial aluminum alloys from the 6000 series, EN AW-6060 and EN AW-6082. The investigation included changes in the mechanical and electrical properties as well as microstructural changes during TMT. Hardness, microhardness and electrical conductivity were studied as a function of the deformation applied after the aging treatment. The deformed samples were compared with the quenched and aged samples. The applied deformation caused an increase in the mechanical properties and a decrease in the electrical properties (electrical conductivity). The highest values for the mechanical properties were achieved after a 50-\% deformation. SEM/EDS microstructural investigations showed the number of precipitated phases. The ratio of silicon and magnesium atoms in the main hardening metastable $\beta^{\prime \prime}$ phase in the deformed samples was closer to the ideal compared with the aged ones.

Keywords: aluminum alloys, EN AW-6082, EN AW-6060, thermomechanical treatment (TMT)

V članku avtorji opisujejo raziskavo vpliva termomehanske obdelave (TMT) na različne lastnosti dveh komercialnih aluminijevih zlitin vrste 6000: EN AW-6060 in EN AW-6082. Raziskava je vključevala spremembe mehanskih in električnih lastnosti, kakor tudi mikrostrukturne spremembe med TMT. Zasledovali so trdoto, mikrotrdoto in električno prevodnost v odvisnosti od uporabljene deformacije po staranju zlitin. Deformirane vzorce so avtorji med seboj primerjali v gašenem in staranem stanju. Povečana stopnja deformacije je povzročila povečanje mehanskih lastnosti in zmanjšanja električne prevodnosti. Najvišje vrednosti mehanskih lastnosti so dobili po $50 \%$ stopnji deformacije. SEM/EDS mikrostrukturne analize so pokazale izločke številnih faz. V primerjavi s staranimi vzorci je bilo v deformiranih vzorcih razmerje med $\mathrm{Si}$ in $\mathrm{Mg}$ atomi $\mathrm{v}$ glavni metastabilni utrjevalni fazi $\beta$ " blizu idealnega.

Ključne besede: zlitine na osnovi aluminija, EN AW-6082, EN AW-6060, termomehanska obdelava
\end{abstract}

\section{INTRODUCTION}

Commercial 6000-series aluminum alloys (Al-Mg-Si) are widely used in many applications due to their excellent properties and exceptional increase in the strength with precipitation hardening (aging). ${ }^{1-7}$ Precipitation hardening can be influenced by a number of parameters, and one of them is deformation. In order to influence the structure by combining deformation with aging, deformation is applied to the samples with thermomechanical treatment (TMT). A typical thermomechanical treatment of $\mathrm{Al}-\mathrm{Mg}-\mathrm{Si}$ alloys includes the deformation of the samples before the aging but after the solution treatment. Studies are often focused on the conventional TMT where a severe plastic deformation (SPD) is applied before the aging. D. Shamas et al. ${ }^{8}$ investigated the influence of TMT on mechanical properties by applying deformation after the solutionizing and before the aging. The results showed that the values of the mechanical properties of the deformed samples

*Corresponding author's e-mail:

ustamenkovic@tfbor.bg.ac.rs (Uroš Stamenković) were higher by $30-60 \%$ (T8 temper) in comparison to the aged ones (T6 temper). G. Angella et al..$^{9}$ used equal channel angular pressing (ECAP) and achieved better precipitation and higher values for the microhardness even after only one pass-through. D. Terada et al. ${ }^{10}$ obtained a hardness value of about $150 \mathrm{HV}$ for the samples deformed by an accumulative roll-bonding process after the solutionizing and before the aging at $170{ }^{\circ} \mathrm{C}$. M. Fujda et al. ${ }^{11}$ investigated the EN AW-6063 and EN AW-6082 alloys after ECAP and the subsequent aging. The highest hardness values were obtained after the deformation, while the subsequent aging had either no effect or even slightly decreased the hardness values. E. Bobruk et al. ${ }^{12}$ obtained higher tensile-strength values for pre-deformed samples compared with the samples which were only aged. Z. Pakiela et al. ${ }^{13}$ showed no influence of prior deformation on the electrical conductivity values for the aged EN AW-6201 and EN AW-6101 alloys. However, K. Majchrowicz et al..$^{14}$ confirmed an increase in the electrical conductivity of the previously deformed and aged EN AW-6101 alloy compared with the aged one. 
According to the literature, research groups were mainly focused on the study of the influence of prior deformation on the mechanical, electrical and microstructural changes in aged samples. There is little information about the influence of deformation on the property changes to aged aluminium alloys. Therefore, the goal of this paper is to investigate the influence of deformation on the properties of aged EN AW-6060 and EN AW-6082 alloys (T9 temper). Deformation was conducted using cold rolling at relatively small deformation degrees compared with the other studies. ${ }^{9-17}$

\section{EXPERIMENTAL PART}

Two commercial 6000-series aluminum alloys were chosen for the experimental investigation, EN AW-6060 and EN AW-6082. The alloys were delivered from "AlCu metali d.o.o.", in the peak-aged condition (T6 temper) and in the form of extruded rectangular bars. Their chemical compositions were determined using an optical emission spectrometer, Belec Compact Port, and it is presented in Table 1. In order to remove the peak-aged condition and obtain the O-temper, all of the samples were subjected to annealing at $550{ }^{\circ} \mathrm{C}$ for $6 \mathrm{~h}$ in an electric resistance furnace, Heraeus K-1150/2. After that, solution heat treatment was performed at $550^{\circ} \mathrm{C}$ for $1 \mathrm{~h}$, followed by quenching in water with ice cubes in order to obtain a supersaturated solid solution $\left(\alpha_{\text {ssss }}\right)$. After obtaining the supersaturated solid solution, the EN AW-6060 and EN AW-6082 samples were subjected to aging at $180{ }^{\circ} \mathrm{C}$ for $5 \mathrm{~h}$ or $6 \mathrm{~h}$, respectively. After the aging, the samples were cold rolled at $(20,30,40$ and 50) $\%$ deformation degrees. A schematic illustration of the applied TMT is presented in Figure 1. The properties of the deformed samples were compared with the quenched and aged ones. Hardness measurements were performed on a VEB Leipzig Vickers hardness tester with a 10-kg load and a 15-s dwell time. In addition, the microhardness values were measured using a PMT-3 Vickers microhardness tester using 100-gf loads with a load duration of $15 \mathrm{~s}$. Both hardness and microhardness measurements followed the ASTM E384 standard. ${ }^{18}$ An electrical conductivity tester, Sigma test 2.063, was used to measure the electrical conductivity. Metallographicphase investigations, the distribution of phases as well as

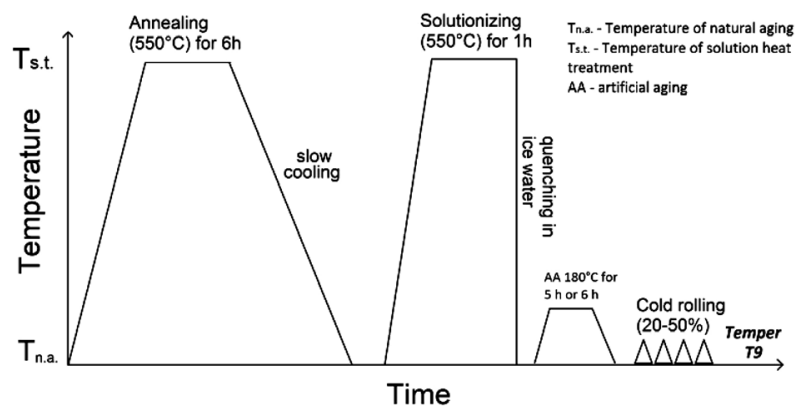

Figure 1: Schematic illustration of the applied TMT the mapping of elements were investigated using a Tescan Vega 3 LMU scanning electron microscope equipped with an EDS X-act detector by Oxford Instruments.

Table 1: Chemical compositions of the investigated alloys (w/\%)

\begin{tabular}{|c|c|c|}
\hline & EN AW-6060 & EN AW-6082 \\
\hline$S i$ & 0.49 & 0.807 \\
\hline$F e$ & 0.182 & 0.354 \\
\hline$C u$ & 0.012 & 0.042 \\
\hline$M n$ & 0.006 & 0.453 \\
\hline$M g$ & 0.594 & 0.696 \\
\hline$C r$ & $<0.003$ & $<0.012$ \\
\hline$N i$ & 0.028 & 0.012 \\
\hline$Z n$ & 0.01 & 0.115 \\
\hline$T i$ & 0.005 & 0.025 \\
\hline$P b$ & $<0.003$ & 0.01 \\
\hline$V$ & 0.014 & $<0.003$ \\
\hline$C o$ & $<0.003$ & 0.006 \\
\hline$S n$ & $<0.003$ & $<0.003$ \\
\hline$Z r$ & $<0.003$ & $<0.003$ \\
\hline$A l$ & 98.62 & 97.45 \\
\hline
\end{tabular}

\section{RESULTS AND DISCUSSION}

Figure 2 represents the influence of the deformation degree after aging on the hardness of the EN AW-6060 and EN AW-6082 alloys. All the deformed as well as aged only samples have higher hardness values in comparison with the quenched samples. The hardness gradually increases for both alloys. The aged only samples $\left(95 \mathrm{HV}_{10}\right.$ ) have a $69.6-\%$ relative hardness increase compared with the quenched sample $\left(56 \mathrm{HV}_{10}\right)$ of the EN AW-6060 alloy. The increase for the sample of the EN AW-6082 alloy that was only aged $\left(124 \mathrm{HV}_{10}\right)$ is $74.6 \%$ in comparison with the quenched sample $\left(71 \mathrm{HV}_{10}\right)$. Subsequently, the hardness continues to increase with the increasing degree of deformation. The maximum values are achieved after $40-\%$ and $50-\%$ deformation of the EN AW-6060 and EN AW-6082 alloys, respectively. The relative hardness increase of the deformed sample, relative to the quenched sample, is $78.6 \%$ and for the aged only EN AW-6060 sample, it is $5.26 \%$; for the EN AW-6082 alloy, the relative increases are $111.3 \%$ and $21 \%$, respectively.

The influence of the deformation degree on the microhardness of the EN AW-6060 and EN AW-6082 alloys after aging is shown in Figure 3. The microhardness values show the same trend as the hardness values. The EN AW-6060 samples that were only aged $\left(110 \mathrm{HV}_{0.1}\right)$ have a $42.8-\%$ relative-microhardness increase in comparison with the quenched sample (77 $\left.\mathrm{HV}_{0.1}\right)$. The EN AW-6082 sample that was only aged $\left(146 \mathrm{HV}_{0.1}\right)$ has a 55.3-\% increase in comparison with the quenched sample $\left(94 \mathrm{HV}_{0.1}\right)$. For both alloys, the maximal microhardness values are obtained after the $50-\%$ deformation. The relative increase in the micro- 


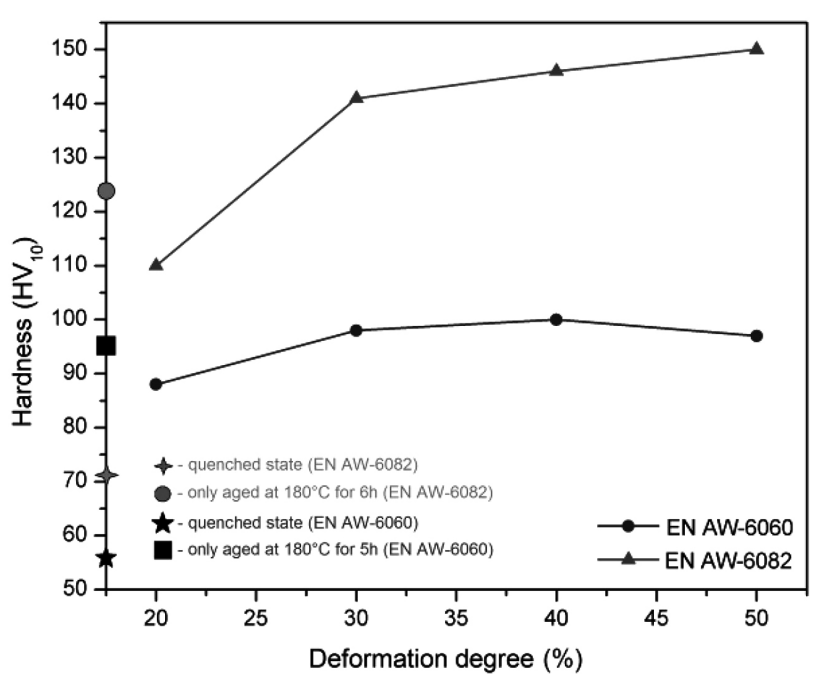

Figure 2: Influence of the deformation degree on the hardness of aged alloys

hardness value of the EN AW-6060 deformed sample relative to the quenched sample is $67.5 \%$ and with respect to the aged one, it is $17.3 \%$; for the EN AW-6082 alloy, it is $101.1 \%$ and $29.4 \%$, respectively.

For both alloys, electrical-conductivity values for the samples that were only aged are higher than those for the quenched state. The relative increase for the $\mathrm{EN}$ AW-6060 sample that was only aged in comparison with the quenched state was $7.8 \%$, and for EN AW-6082, it was $7.2 \%$. For the EN AW-6060 alloy, all the deformed samples have higher electrical-conductivity values compared with the quenched samples. For the EN AW-6082 alloy, the 50-\% deformed samples have lower electricalconductivity values in comparison with the quenched state. The electrical-conductivity values significantly decrease with an increase in the deformation degree after aging. The minimal values are obtained at the highest deformation degree. The relative decrease in the elec-

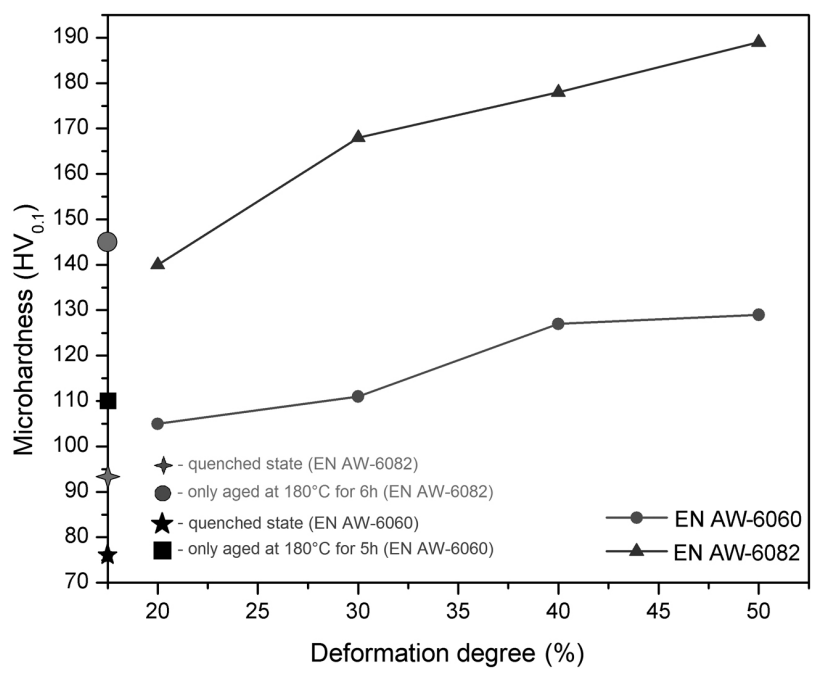

Figure 3: Influence of the deformation degree on the microhardness of aged alloys

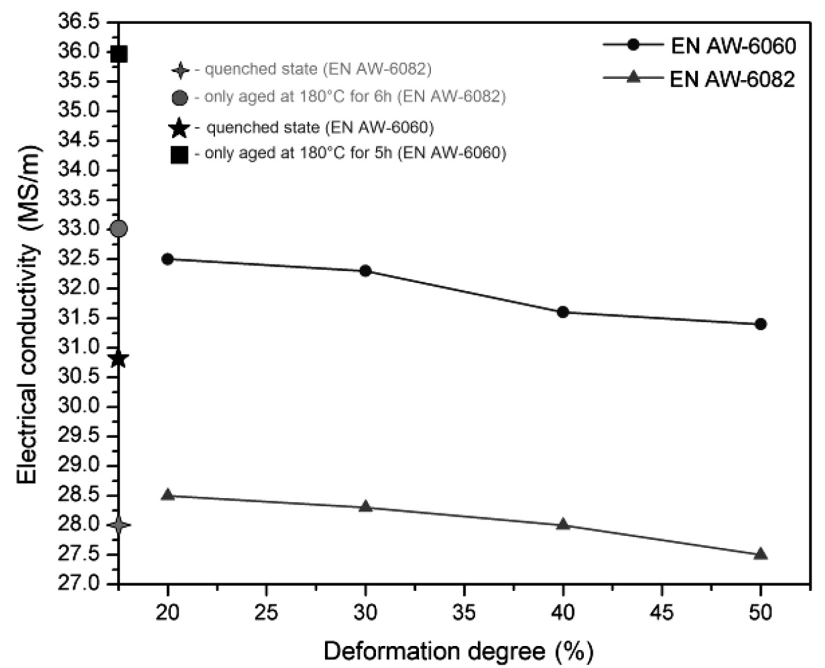

Figure 4: Influence of the deformation degree on the electrical conductivity of aged alloys

trical conductivity of the 50-\% deformed samples relative to the aged ones is $5.42 \%$ for EN AW-6060 and $8.39 \%$ for EN AW-6082.

The deformation caused by cold rolling after artificial aging led to reactions between the newly introduced dislocations and precipitated particles presented in the microstructure after the artificial aging. According to S. Dadbakhsh et al., ${ }^{19}$ the metastable $\beta^{\prime \prime}$ phase is very effective in blocking as well as in multiplying dislocations. Therefore, hardness and microhardness values increase when deformation is applied after artificial aging, as suggested by P. Serrao et al. ${ }^{20}$. During the

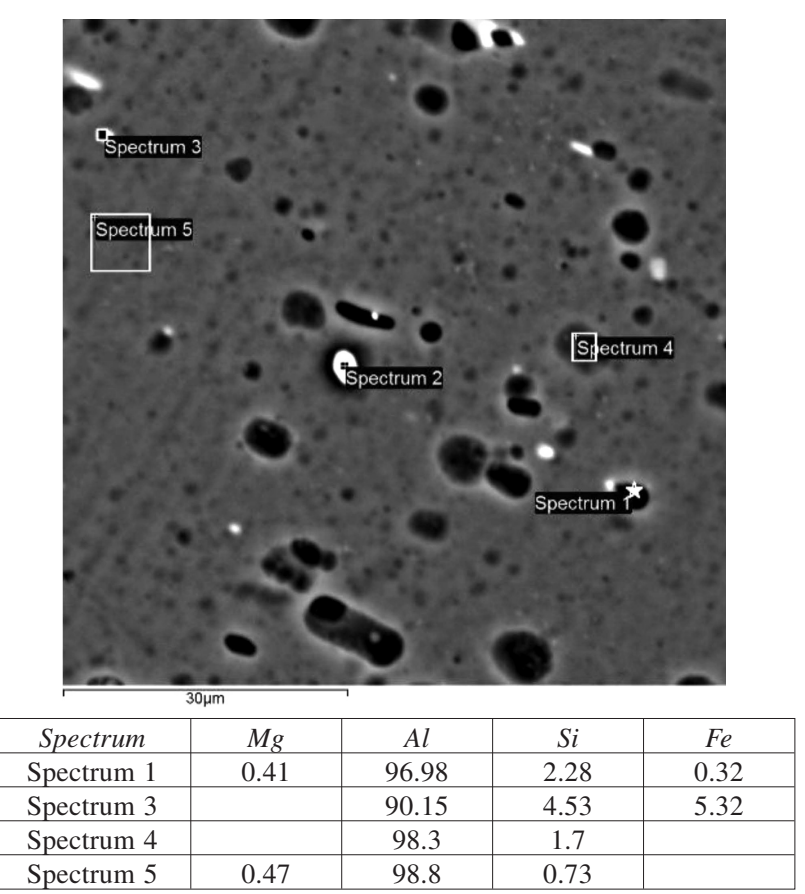

Figure 5: SEM-EDS analyses of aged EN AW-6060 alloy (at $180{ }^{\circ} \mathrm{C}$ for $5 \mathrm{~h}$ ) (EDS results are in $a / \%$ ) 


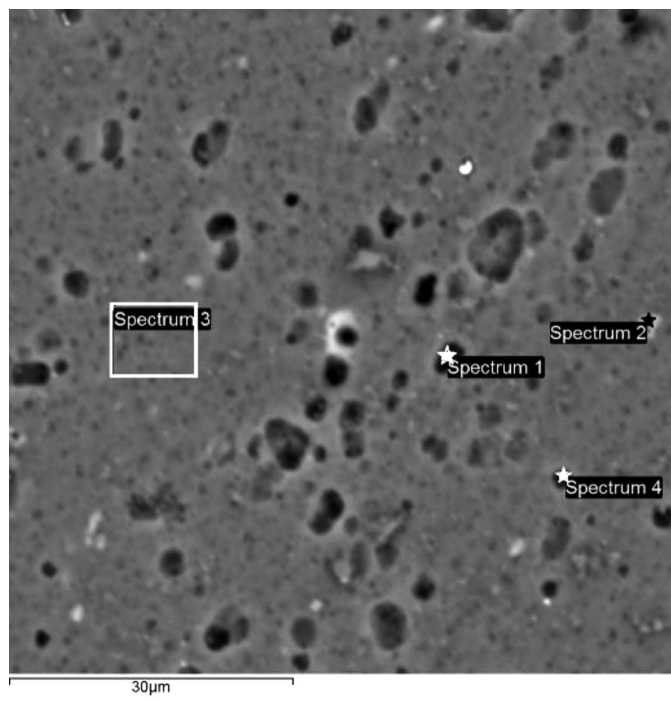

\begin{tabular}{|c|c|c|c|c|c|}
\hline Spectrum & $M g$ & $A l$ & $S i$ & $M n$ & $F e$ \\
\hline Spectrum 1 & 0.35 & 98.69 & 0.26 & 0.33 & 0.36 \\
\hline Spectrum 2 & & 89.67 & 4.4 & 1.88 & 4.05 \\
\hline Spectrum 3 & 0.42 & 98.68 & 0.9 & & \\
\hline Spectrum 4 & & 99.21 & 0.53 & 0.26 & \\
\hline
\end{tabular}

Figure 6: SEM-EDS analyses of aged EN AW-6082 alloy (at $180{ }^{\circ} \mathrm{C}$ for $6 \mathrm{~h})($ EDS results are in $a / \%)$

deformation, the crystal lattice is probably being distorted due to the crystal-plane sliding. The change in the relative orientation and position of the atoms in the crystal lattice causes the change in the electric potential. The movement of electrons is hindered by the distortion of the crystal lattice. As the deformation degree increases, the dislocation density increases by several orders of magnitude and the electrical conductivity decreases due to electron scattering. ${ }^{21}$

In order to study the microstructure in more detail, both the aged samples and the ones that were aged and deformed at the highest degree of deformation were analyzed with SEM-EDS and compared. Figure 5 shows the SEM microstructure of the EN AW-6060 alloy after aging at $180{ }^{\circ} \mathrm{C}$ for $5 \mathrm{~h}$, along with the EDS analysis of the precipitated phases. All the results of the EDS analysis are given in atomic percent. The microstructure of the EN AW-6082 alloy after aging at $180{ }^{\circ} \mathrm{C}$ for $6 \mathrm{~h}$ is given in Figure 6. In both alloys, the matrix is covered with finely dispersed particles of the metastable $\beta$ " phase, represented by Spectrum 5 in Figure 5 and Spectrum 3 in Figure 6. The ideal ratio of $\mathrm{Mg}: \mathrm{Si}$ in the $\beta^{\prime \prime}$ phase, according to C. D. Marrioara et al., ${ }^{4-6}$ is 5:6. In both samples, the ideal ratio was not achieved, probably due to excess silicon and a lack of homogeneity. In both microstructures there is a phase that appears white. For the EN AW-6060 alloy, it is the ternary AlFeSi phase and for EN AW-6082, it is the quaternary AlMnFeSi phase due to the presence of manganese in the alloy. These phases are represented by Spectrum 3 in Figure 5 and Spectrum 2 in Figure 6. Slightly larger particles, black in color and containing all the detected elements are present in both

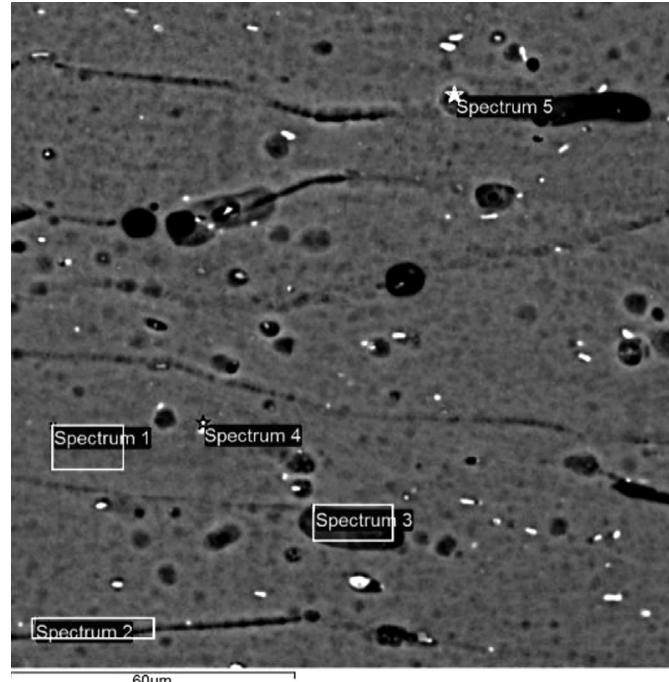

\begin{tabular}{|c|c|c|c|c|c|c|}
\hline Spectrum & $M g$ & $A l$ & $S i$ & $M n$ & $F e$ & $N i$ \\
\hline Spectrum 1 & 0.54 & 98.75 & 0.71 & & & \\
\hline Spectrum 2 & 0.63 & 97.36 & 1.24 & 0.27 & 0.5 & \\
\hline Spectrum 3 & 0.69 & 99.31 & & & & \\
\hline Spectrum 4 & & 97.9 & & 0.87 & 1.23 & \\
\hline Spectrum 5 & & 83.39 & 7.09 & 1.87 & 6.98 & 0.67 \\
\hline
\end{tabular}

Figure 7: SEM-EDS analyses of EN AW-6060 alloy, $50 \%$ deformed after aging at $180{ }^{\circ} \mathrm{C}$ for $5 \mathrm{~h}$ (EDS results are in $\mathrm{a} / \%$ )

alloys. They are represented by Spectrum 1 in both Figures 5 and 6.

Figures 7 and $\mathbf{8}$ show microphotographs of the EN AW-6060 and EN AW-6082 samples with a 50-\% deformation after the aging. In both alloys, the matrix is

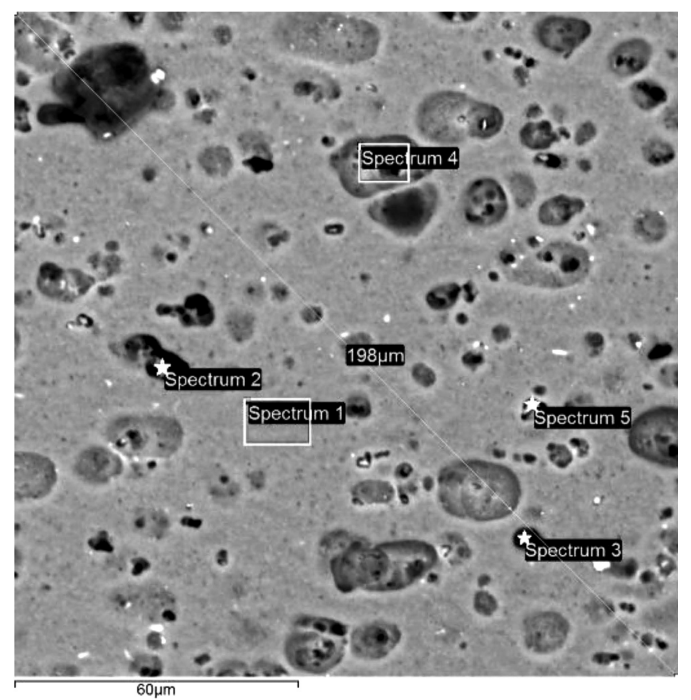

\begin{tabular}{|c|c|c|c|c|c|}
\hline Spectrum & $M g$ & $\mathrm{Al}$ & $\mathrm{Si}$ & $\mathrm{Fe}$ & $\mathrm{Ni}$ \\
\hline Spectrum 1 & 0.55 & 98.85 & 0.6 & & \\
\hline Spectrum 2 & 0.54 & 98.7 & 0.76 & & \\
\hline Spectrum 3 & 0.54 & 98.84 & 0.62 & & \\
\hline Spectrum 4 & & 88.08 & 3.59 & 6.07 & 2.26 \\
\hline Spectrum 5 & 0.49 & 99.03 & 0.48 & & \\
\hline
\end{tabular}

Figure 8: SEM-EDS analyses of EN AW-6082 alloy, $50 \%$ deformed after aging at $180^{\circ} \mathrm{C}$ for $6 \mathrm{~h}$ (EDS results are in $a / \%$ ) 

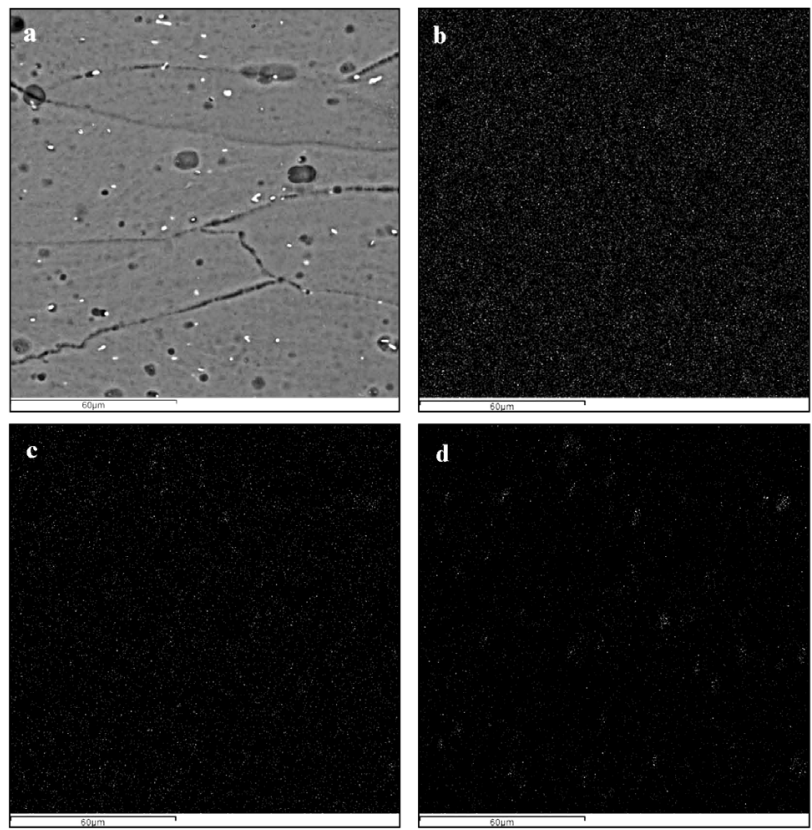

Figure 9: Maps of the element distribution in EN AW-6060 deformed by $50 \%$ after aging at $180{ }^{\circ} \mathrm{C}$ for $5 \mathrm{~h}$ : a) analyzed SEM microstructure, b) $\mathrm{Mg}$, c) $\mathrm{Si}$, d) $\mathrm{Fe}$

covered with finely dispersed particles of the metastable $\beta$ " phase, represented by Spectrum 1 in Figures 7 and 8 . Comparing the EDS results with the ones for the aged samples (Figures 5 and 6), it can be seen that the ratio of $\mathrm{Mg}: \mathrm{Si}$ is now closer to ideal. It can be concluded that the deformation had a very positive effect on the distribution of the metastable $\beta$ " phase, which resulted in an increase in the hardness and microhardness values.

A high dispersion of particles and a good phase redistribution were mentioned by other authors when deformation was applied after the standard heat treat ment. ${ }^{8-10,14,19}$ A phase that is white in color appears again in both samples. For the EN AW-6060 alloy, it is shown in Figure 7 as Spectrum 4, and for the EN AW-6082 alloy, it is given in Figure 8 as Spectrum 5. It is similar to the phase that appears in the aged samples, but in the deformed samples, it also contains nickel. This can be ascribed to the accelerated diffusion that allowed the movement of nickel atoms due to deformation. To further investigate the dispersion and homogeneity, the distribution of elements in the structure was investigated with EDS mapping. The distribution of elements in the EN AW-6060 and EN AW-6082 samples deformed by $50 \%$ after the aging is given in Figures 9 and 10, respectively.

From Figures 9 and 10, it can be seen that magnesium and silicon atoms were uniformly distributed throughout the entire microstructure of the analyzed samples, without any of clusters. Iron and manganese atoms tend to bind with aluminum and silicon, so the grouping of these elements can be observed in their distribution maps (Figures 9e and 10e). From the presented figures (Figures $\mathbf{7}$ and $\mathbf{8}$ ), it can be concluded that there is a grain and particle orientation in the direction of
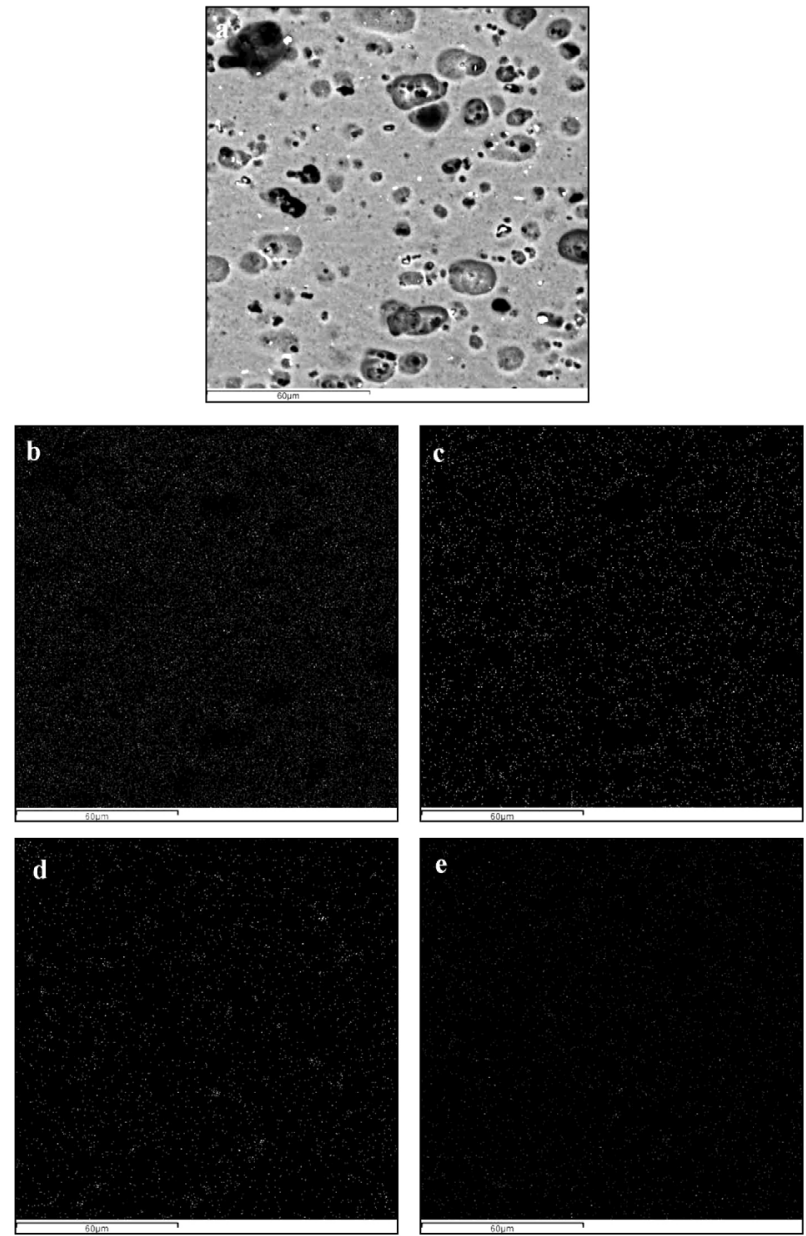

Figure 10: Maps of the element distribution in EN AW-6082 deformed by $50 \%$ after aging at $180{ }^{\circ} \mathrm{C}$ for $6 \mathrm{~h}$ : a) analyzed SEM microstructure, b) $\mathrm{Mg}$, c) $\mathrm{Si}$, d) Fe, e) $\mathrm{Mn}$

rolling. L. Li et al. ${ }^{22}$ clearly showed the orientation of super-pure aluminum grains after a deformation.

\section{CONCLUSIONS}

According to the results obtained during the investigation of the effect of a thermomechanical treatment on different properties of the EN AW-6060 and EN AW-6082 alloys, the following conclusions can be drawn:

- The applied TMT has a significant impact on the mechanical and structural properties of the investigated alloys. A greater influence of TMT is achieved in the EN AW-6082 alloy that contains more alloying elements.

- The hardness and microhardness gradually increase with the deformation degree after aging (T9 temper). The hardness slightly increases from $95 \mathrm{HV}_{10}$ for the aged EN AW-6060 samples to $100 \mathrm{HV}_{10}$ after the aging and $40-\%$ deformation. This increase is more evident for the EN AW-6082 alloy where the hardness increases from $124 \mathrm{HV}_{10}$ in the aged state to 
$150 \mathrm{HV}_{10}$ after the 50-\% deformation. The relative increase in the microhardness of the deformed samples relative to the aged ones was $17.3 \%$ (from $110 \mathrm{HV}_{0.1}$ to $129 \mathrm{HV}_{0.1}$ ) for the EN AW-6060 alloy and $29.4 \%$ (from $146 \mathrm{HV}_{0.1}$ to $189 \mathrm{HV}_{0.1}$ ) for the $\mathrm{EN}$ AW-6082 alloy.

- The electrical conductivity of the aged samples gradually decreases with an increase in the applied deformation. The relative decrease in the electrical conductivity of the deformed samples relative to the aged ones is $5.42 \%$ for EN AW-6060 and $8.39 \%$ for EN AW-6082.

- The matrix of the investigated alloys is covered with finely dispersed particles of the metastable $\beta^{\prime \prime}$ phase. The ratio of $\mathrm{Mg}: \mathrm{Si}$ in the metastable $\beta^{\prime \prime}$ phase in deformed samples is closer to the ideal, indicating a positive effect of the deformation on the distribution of alloying elements.

- Maps of the element distribution in the post-deformed state show excellent homogeneity and distribution of the elements. The clustering of iron, nickel and silicon atoms is noticed while magnesium and silicon are uniformly distributed within the matrix.

\section{Acknowledgment}

The research presented in this paper was done with the financial support of the Ministry of Education, Science and Technological Development of the Republic of Serbia, within the funding of the scientific research work at the University of Belgrade, Technical Faculty in Bor, according to the contract with registration number 451-03-68/2020-14/ 200131.

\section{REFERENCES}

${ }^{1}$ Y. Birol, The effect of processing and Mn content on the T5 and T6 properties of AA6082 profiles, J. Mater. Process. Technol., 173 (2006) 1, 84-91, doi:10.1016/j.jmatprotec.2005.09.029

${ }^{2}$ Y. Birol, Precipitation during homogenization cooling in $\mathrm{AlMgSi}$ alloys, T. Nonferr. Metal. Soc., 23 (2013) 7, 1875-1881, doi:10.1016/S1003-6326(13)62672-2

${ }^{3}$ T. R. Prabhu, Effects of ageing time on the mechanical and conductivity properties for various round bar diameters of AA 2219 Al alloy, Eng. Sci. Technol. Int. J., 20 (2017) 1, 133-142, doi:10.1016/ j.jestch.2016.06.003

${ }^{4}$ C. D. Marioara, H. Nordmark, S. J. Andersen, R. Holmestad, Post$\beta$ " phases and their influence on microstructure and hardness in 6xxx Al-Mg-Si alloys, J. Mater. Sci., 41 (2006) 2, 471-478, doi:10.1007/ s10853-005-2470-1

${ }^{5}$ C. D. Marioara, S. J. Andersen, J. Jansen, H. W. Zandbergen, Atomic model for GP-zones in a 6082 Al-Mg-Si system, Acta Mater., 49 (2001) 2, 321-328, doi:10.1016/S1359-6454(00)00302-5

${ }^{6}$ C. D. Marioara, S. J. Andersen, J. Jansen, H. W. Zandbergen, The influence of temperature and storage time at RT on nucleation of the $\beta "$ phase in a $6082 \mathrm{Al}-\mathrm{Mg}-\mathrm{Si}$ alloy, Acta Mater., 51 (2003) 3, 789-796, doi:10.1016/S1359-6454(02)00470-6

${ }^{7}$ T. Abid, A. Boubertakh, S. Hamamda, Effect of pre-aging and maturing on the precipitation hardening of an $\mathrm{Al}-\mathrm{Mg}-\mathrm{Si}$ alloy, $\mathrm{J}$.
Alloys Compd., 490 (2010) 1-2, 166-169, doi:10.1016/j.jallcom. 2009.10.096

${ }^{8}$ D. Shamas, J. Kamran, H. Bin Awais, T. H. Naeem, M. Mazher, M. Shamas uz Zuha, Effect of thermo mechanical treatments and aging parameters on mechanical properties of $\mathrm{Al}-\mathrm{Mg}-\mathrm{Si}$ alloy containing 3 wt.\% Li, Mater. Design, 64 (2014), 366-373, doi:10.1016/j.matdes. 2014.07.062

${ }^{9}$ G. Angella, P. Bassani, A. Tuissi, M. Vedani, Aging Behaviour and Mechanical Properties of a Solution Treated and ECAP Processed 6082 Alloy, Mater. Trans., 45 (2004) 7, 2282-2287, doi:10.2320/ matertrans.45.2282

${ }^{10}$ D. Terada, Y. Kaneda, Z. Horita, K. Matsuda, S. Hirosawa, N. Tsuji, Mechanical properties and microstructure of 6061 aluminum alloy severely deformed by ARB process and subsequently aged at low temperatures, Proc. of the IOP Conf. Ser.: Mater. Sci. Eng., 63 (2014), 012088, doi:10.1088/1757-899X/63/1/012088

${ }^{11}$ M. Fujda, M. Matvija, T. Kvačkaj, O. Milkovič, P. Zubko, K. Nagyová, Structure and properties of AlMgSi alloys after ECAP and post-ECAP ageing, Mater. Tehnol., 46 (2012) 5, 465-469, UDK 669.715:621.785.7:620.17

${ }^{12}$ E. Bobruk, I. Sabirov, V. Kazykhanov, R. Valiev, M. Murashkin, Microstructure features and mechanical properties of a UFG Al-Mg-Si alloy produced via SPD, Proc. of the IOP Conf. Ser.: Mater. Sci. Eng., 63 (2014), 012116, doi:10.1088/1757-899X/ $63 / 1 / 012116$

${ }^{13}$ Z. Pakiela, K. Ludwichowska, J. Ferenc, M. Kulczyk, Mechanical properties and electrical conductivity of Al 6101 and 6201 alloys processed by hydro-extrusion, Proc. of the IOP Conf. Ser.: Mater. Sci. Eng., 63 (2014), 012120, doi:10.1088/1757-899X/63/1/012120

${ }^{14}$ K. Majchrowicz, Z. Pakieła, W. Chrominski, M. Kulczyk, Enhanced strength and electrical conductivity of ultrafine-grained Al-Mg-Si alloy processed by hydrostatic extrusion, Mater. Charact., 135 (2018), 104-114, doi:10.1016/j.matchar.2017.11.023

${ }^{15}$ W. Chrominski, S. Wenner, C. D. Marioara, R. Holmestad, M. Lewandowska, Strengthening mechanisms in ultrafine grained Al-Mg-Si alloy processed by hydrostatic extrusion - Influence of ageing temperature, Mater. Sci. Eng. A, 669 (2016), 447-458, doi:10.1016/j.msea.2016.05.109

${ }^{16}$ Z. Martinova, D. Damgaliev, M. Hirsh, The effect of room temperature pre-ageing on tensile and electrical properties of thermomechanically treated Al-Mg-Si alloy, J. Min. Metall. B, 38 (2002) 1-2, 61-73, doi:10.2298/JMMB0202061M

${ }^{17}$ M. Bournane, A. Berezina, O. Davydenko, T. Monastyrska, O. Molebny, V. Spuskanyuk, A. Kotko, Effect of Severe Plastic Deformation on Structure and Properties of Al-Mg-Si Alloy of 6060 Type, Materials Science and Metallurgy Engineering, 1 (2013) 2, 13-21, doi:10.12691/msme-1-2-1

${ }^{18}$ ASTM E384 - 17: Standard Test Method for Microindentation Hardness of Materials, Developed by Subcommittee E04.05, https://www.astm.org/Standards/E384.htm

${ }^{19}$ S. Dadbakhsh, A. Karimi Taheri, C. W. Smith, Strengthening study on $6082 \mathrm{Al}$ alloy after combination of aging treatment and ECAP process, Mater. Sci. Eng. A, 527 (2010) 18-19, 4758-4766, doi:10.1016/j.msea.2010.04.017

${ }^{20}$ P. Serrao, B. P. Chiranth, N. Vaz, A. Fernandis, P. Rao, V. Shambulingesh, Effect of Equal Chanel Angular Pressing and Age Hardening on the Hardness of Al-Mg-Si Alloy, Am. J. Mater. Sci., 7 (2017) 5, 150-155, doi:10.5923/j.materials.20170705.06

${ }^{21}$ J. A. Omotoyinbo, I. O. Oladele, W. Shokoya, Effect of the Degree of Plastic Deformation on the Electrical Resistance and Thermal Conductivity of Al-Mg-Si Alloy, Leonardo El. J. Pract. Technol., 13 (2014) 24, 37-50

${ }^{22}$ L. Li, J. Wang, S. Gao, Microstructure and Mechanical Properties of High-Purity Aluminum Deformed with Equal-Channel Angular Pressing, Mater. Tehnol., 52 (2018) 6, 723-729, doi:10.17222/ mit.2018.068 